\title{
Pengaturan Pelaksanaan Pemilihan Kepala Daerah Serentak
}

\author{
R. Nazriyah \\ Fakultas Ekonomi Universitas Muhammadiyah Gresik \\ Jl. Sumatera No. 101 GKB Gresik \\ ririesnaya@yahoo.com
}

\begin{abstract}
The issues to be examined in this research is how does the practice of simultaneous Local Election according to the valid legislation and which institution is authorized to settle the disputes of simultaneous local elections? This research is normative. The study found that Article 3 (1) regulation number 12014 About the Election of governors, regents and mayors passed into law No. 1 Year 2015 on the Election of governors, regents, and the Mayor state that, the local election is held every 5 (five) years simultaneously throughout the territory of the Republic of Indonesia. The Local Election schedule is implemented in several periods. Meanwhile the simultaneous national elections is held in 2027. Law No. 12015 mandates the Constitutional Court to resolve the dispute over the local elections, despite the fact that it is unlikely for one institution to examine and judge hundreds of cases of disputed local elections at the same time. Local Election dispute resolution processes also have a specified time limit. To that end, the institutions considered most appropriate to handle election disputes is the Supreme Court by delegating the High Court in each region. If litigants are not satisfied with the decision of the High Court then, they may appeal to the Supreme Court.
\end{abstract}

Keywords: Disputes, election, simultaneous, state agencies

\begin{abstract}
Abstrak
Permasalahan yang akan diteliti adalah bagaimana pelaksanaan Pilkada serentak berdasarkan peraturan perundang-undangan yang berlaku dan lembaga mana yang berwenang menyelesaikan sengketa Pilkada serentak? Penelitian ini merupakan penelitian normatif. Hasil penelitian menemukan bahwa Pasal 3 (1) Perppu nomor 1 Tahun 2014 Tentang Pemilihan Gubernur, Bupati, dan Walikota yang disahkan menjadi UU No. 1 Tahun 2015 tentang Pemilihan Gubernur, Bupati, dan Walikota menyatakan bahwa, pemilihan Kepala Daerah dilaksanakan setiap 5 (lima) tahun sekali secara serentak di seluruh wilayah Negara Kesatuan Republik Indonesia. Jadwal Pilkada dilaksanakan dalam beberapa gelombang. Sedangkan Pilkada serentak nasional dilaksanakan pada 2027. UU No. 1 Tahun 2015 masih menyerahkan kepada Mahkamah Konstitusi untuk menyelesaikan sengketa Pilkada, tidak mungkin satu institusi memeriksa dan memutus beratus-ratus kasus sengketa Pilkada dalam waktu yang bersamaan. Proses penyelesaian sengketa Pilkada juga mempunyai batas waktu yang telah ditentukan. Untuk itu, lembaga yang dianggap paling pas menangani sengketa Pilkada adalah Mahkamah Agung dengan mendelegasikan kepada Pengadilan Tinggi di tiap-tiap daerah. Jika pihak yang berperkara tidak puas dengan putusan Pengadilan Tinggi maka, dapat mengajukan keberatan ke Mahkamah Agung.
\end{abstract}

Kata Kunci : Sengketa, pilkada, serentak, lembaga negara 


\section{Pendahuluan}

Mahkamah Konstitusi (MK) telah mengabulkan uji materi (judicial review) Undang-Undang Nomor 42 Tahun 2008 tentang Pemilihan Presiden dan Wakil Presiden yang diajukan akademisi Effendi Ghazali bersama Koalisi Masyarakat untuk Pemilu Serentak. ${ }^{1}$ Putusan tersebut berlaku pada Pemilihan Presiden 2019. Dengan dikabulkannya gugatan ini, pelaksanaan Pemilihan Umum (Pemilu) legislatif dan presiden pada tahun 2019 mendatang akan dilaksanakan secara serentak. Hal itu ditetapkan dalam Putusan MK No. 14/PUU-XI/2013 guna untuk menghemat biaya pemilu.

Salah satu alasan pemohon adalah sebagai berikut: ${ }^{2}$ Hak warga negara untuk memilih secara efisien pada pemilihan umum serentak terkait dengan penggunaan waktu, energi, biaya warga negara untuk melaksanakan Hak Pilihnya yang lebih terjamin dengan penyelenggaraan Pemilihan Umum Serentak. Tentu hal ini amat erat kaitannya dengan Partisipasi Politik Warga Negara untuk memilih. Walau masih terbuka beberapa alasan untuk tidak menggunakan Hak Pilih, namun jika Pemilihan Umum dilaksanakan sesuai amanat Konstitusi yaitu lima tahun sekali (serentak) untuk memilih (sekaligus) anggota DPR, DPD, DPRD, serta Presiden dan Wakil Presiden, maka setidaknya setiap Pemilihan Umum akan mendapatkan partisipasi pemilih yang paling tinggi di antara Pemilu DPR, DPR, dan DPRD, dengan Pemilu Presiden dan Wakil Presiden. Angka selisihnya (yang bisa berarti warga negara yang terhambat dalam penggunaan waktu, energi, dan biaya untuk melaksanakan Hak Pilihnya) amat signifikan. Pada 2004, selisihnya 2.155.194 Pemilih. Pada 2009, selisihnya 5.591.009 Pemilih.

Pada sisi efisiensi penyelengaraan pemilihan umum, berdasarkan riset pendahuluan Pemohon, perhitungan Pemborosan Penyelenggaraan Pemilu Tidak Serentak (berasal dari APBN \& APBD, dan juga pajak warga negara) bisa berkisar antara 5 hingga 10 Trilyun Rupiah dalam hal Pemilu Presiden dan Wakil Presiden dibuat terpisah dengan Pemilu Anggota DPR/D dan DPD; atau sampai berkisar

\footnotetext{
${ }^{1}$ Pasal yang diajukan uji materi oleh pemohon adalah Pasal 3 ayat (5), Pasal 9, Pasal 12 ayat (1) dan (2), Pasal 14 ayat (2) dan Pasal 112 UU 42 Tahun 2008.

2 Putusan Mahkamah Konstitusi Nomor 14/PUU-XI/2013, hlm. 21-22.
} 
20 hingga 26 Trilyun (karena Pemilu Kepala Daerah tidak dapat dilaksanakan secara serentak pula). Sementara itu Pasal 28H ayat (1) UUD 1945 berbunyi, "Setiap orang berhak hidup sejahtera lahir dan batin, bertempat tinggal, dan mendapat lingkungan hidup yang baik dan sehat serta berhak memperoleh pelayanan kesehatan". Kemudian Pasal 33 ayat (4) UUD 1945, berbunyi, "Perekonomian nasional diselenggarakan berdasar atas demokrasi ekonomi dengan prinsip kebersamaan, efisiensi berkeadilan, berkelanjutan, berwawasan lingkungan, kemandirian, serta dengan menjaga keseimbangan kemajuan dan kesatuan ekonomi nasional". Pasal 28H ayat (1) dan Pasal 33 ayat (4) UUD 1945 adalah salah satu bukti bahwa Indonesia menganut negara kesejahteraan (social service state). Dalam kerangka berpikir negara kesejahteraan, negara bukan hanya berurusan dengan masalah pemberian jaminan kepada individu supaya dapat melaksanakan hak-hak politiknya, tetapi juga meliputi berbagai aspek sosial, budaya, dan ekonomi yang bersifat sangat kompleks. Dengan demikian, penyelenggaraan Pemilu yang dilakukan tidak serentak sehingga tidak efisien melanggar atau mengganggu pemenuhan Hak Konstitusional warga negara untuk hidup sejahtera lahir dan batin serta untuk hidup dalam Sistem Perekonomian Nasional yang diselenggarakan dengan prinsip kebersamaan, efisien berkeadilan dan berkelanjutan (Pasal 28H ayat (1) dan Pasal 33 ayat (4) UUD 1945).

Tetapi, putusan MK itu sama sekali tidak menyinggung pemilihan kepala daerah secara serentak. Dalam Pasal 3 (1) Perppu Nomor 1 Tahun 2014 tentang Pemilihan Gubernur, Bupati, dan Walikota telah menyatakan bahwa, pemilihan dilaksanakan setiap 5 (lima) tahun sekali secara serentak di seluruh wilayah Negara Kesatuan Republik Indonesia.

\section{Rumusan Masalah}

Permasalahan yang akan diteliti adalah, pertama: bagaimana pelaksanaan Pemilukada serentak berdasarkan peraturan perundang-undangan yang berlaku? Kedua, lembaga mana yang berwenang menyelesaikan sengketa Pilkada serentak? 


\section{Tujuan Penelitian}

Tujuan penelitian ini adalah untuk mengetahui: pertama, pelaksanaan Pemilukada serentak berdasarkan peraturan perundang-undangan yang berlaku. Kedua, lembaga yang berwenang menyelesaikan sengketa Pilkada serentak.

\section{Metode Penelitian}

Penelitian ini merupakan penelitian yang bersifat normatif. Pendekatan penelitian yang digunakan meliputi pendekatan undang-undang. Jenis data yang digunakan adalah data sekunder. Sumber data sekunder yang digunakan mencakup bahan hukum primer, bahan hukum sekunder dan bahan hukum tersier. Bahan-bahan hukum primer terdiri dari perundang-undangan, risalah dalam pembuatan perundang-undangan dan putusan-putusan hakim. ${ }^{3}$ Putusan Mahkamah Konstitusi yang diteliti adalah Putusan Mahkamah Konstitusi Nomor 14/PUU-XI/2013 tentang uji materi Undang-Undang Nomor 42 Tahun 2008 tentang Pemilihan Presiden dan Wakil Presiden, karena putusan tersebut berkaitan dengan pokok bahasan. Teknik pengumpulan data yang digunakan berupa bahan pustaka melalui buku-buku literatur, peraturan perundangundangan, serta pengumpulan data, melalui media elektronik yang berhubungan dengan masalah yang diteliti. Data yang terkumpul kemudian dianalisa melalui analisa kualitatif.

\section{Hasil Penelitian dan Pembahasan}

\section{Kontroversi Pemilihan Kepala Daerah Langsung}

Sejalan dengan sistem demokrasi perwakilan, maka secara kelembagaan perlu ada badan perwakilan rakyat daerah yang dibentuk secara demokratik. Demikian pula penyelenggaraan pemerintahannya harus dijalankan secara demokratik yang meliputi tata cara penunjukan pejabat, penentuan kebijakan,

${ }^{3}$ Peter Mahmud Marzuki, Penelitian Hukum, Edisi Pertama,Cetakan Ke-4, Predana Media Group, Jakarta, 2008, hlm. 141. 
pertanggungjawaban, pengawasan, dan lain-lain. Mekanisme pemerintahan harus dilakukan dengan tata cara yang demokratik pula. ${ }^{4}$

Adanya organ politik dalam pelaksanaan otonomi daerah membawa perlunya akses masyarakat terhadap mekanisme pengisian jabatannya. Memang selama ini dapat dilalui dengan demokrasi perwakilan. Tetapi nilai demokrasi tersebut masih perlu dibuka luas lagi dalam demokrasi langsung pada pengisian jabatan politik. ${ }^{5}$

Gagasan demokratisasi pemerintahan dan pergulatan kedaulatan rakyat semakin mendapatkan tempat dengan adanya gagasan untuk pemilihan langsung pimpinan daerah. Gagasan pemilihan langsung kepala daerah ini pun secara formal baru terealisasi pada 2004 dan baru dilaksanakan pada 2005. ${ }^{6}$ Semangat dilaksanakannya Pemilukada langsung adalah koreksi terhadap sistem demokrasi tidak langsung (perwakilan) di era sebelumnya, dimana Kepala daerah dan Wakil Kepala Daerah dipilih oleh DPRD, menjadi demokrasi yang berakar langsung pada pilihan rakyat (pemilih). ${ }^{7}$

Undang-Undang Dasar (UUD 1945) Pasal 18 ayat (4) menegaskan bahwa "Gubernur, Bupati, dan Walikota masing-masing sebagai kepala pemerintahan Provinsi, kabupaten, dan Kota dipilih secara demokratis". Rumusan pasal tersebut dapat ditarik beberapa kesimpulan bahwa: ${ }^{8}$ a) UUD 1945 tidak mengharuskan Kepala Daerah dipilih secara langsung, dan calon Kepala Daerah juga tidak harus berasal dari partai politik atau gabungan partai politik; b) frasa "dipilih secara demokratis" tidaklah dapat ditafsirkan bahwa rekrutmen pasangan calon menjadi kewenangan mutlak partai politik sebagai salah satu lembaga yang berfungsi melakukan rekrutmen politik dalam pengisian jabatan publik melalui mekanisme yang demokratis; c) rumusan Pasal 18 ayat (4) UUD 1945 amandemen kedua 2000 dapat ditafsirkan sama dengan tata cara dan

\footnotetext{
${ }^{4}$ Bagir Manan, Menyongsong Fajar Otonomi Daerah, FH UII Yogyakarta, Cet. III, Yogyakarta, 2004, hlm. 59.

${ }_{5}^{5}$ Muchamad Isnaeni Ramdhan, Kompedium Pemiliban Kepala Daerah (Pilkada), Badan Pembinaan Hukum Nasional Departemen hukum dan HAM RI, Jakarta, 2009, hlm. 22.

${ }^{6}$ Retno Saraswati "Calon Perseorangan: Pergeseran Paradigma Kekuasaan dalam Pemilukada", dalam Masalah-Masalah Hukum, Nomor 2 Jilid 40, April 2011, hlm. 196.

7 Mustafa Lutfi, Hukum Sengketa Pemilukada Di Indonesia Gagasan Perluasan Kewenangan Konstitusional Mahkamah Konstitusi, Cetakan Pertama, UII Press, Yogyakarta, 2010, hlm.130. Melalui pemilihan kepala daerah secara langsung, amggota-anggota DPRD diharapkan tidak lagi menjual suaranya secara eceran kepada calon kepala daerah. Lihat Moh. mahfud MD., Perdebatan Hukum Tata Negara Pasca Amandemen Konstitusi, Cetaka ke-2 RajaGrafindo Persada, Jakarta, 2011, hlm. 169.

${ }^{8}$ Suharizal, Pemilukada, Dinamika, dan Konsep Mendatang, Raja Grafindo Persada, Jakarta, 2011, hlm. 26.
} 
prosedural pemilu sebagaimana dinyatakan dalam beberapa pasal amendemen ketiga 2001. Artinya, pemilukada secara langsung, khususnya lembaga yang memiliki kewenangan melakukan rekrutmen calon Kepala daerah adalah lembaga yang juga menjadi penanggung jawab pelaksanaan pemilu yaitu Komisi Pemilihan Umum; d) Pasal 18 ayat (4) hanya mengharuskan yang dipilih secara demokratis adalah Kepala Daerah (Gubernur, Bupati, dan Walikota). Dengan kata lain Wakil Kepala Daerah (Wakil gubernur, Wakil Bupati, dan Wakil Walikota) tidak harus dipilih satu paket dengan Kepala Daerah. Ketentuan ini juga dapat ditafsirkan bahwa posisi wakil kepala daerah sesungguhnya dapat dihilangkan dalam sistem pemerintahan daerah.

Jika kita menelaah risalah sidang MPR yang merumuskan Pasal 18 ayat (4) UUD 1945, para pembentuk undang-undang dasar memang menyepakati bahwa pemilihan Gubernur, Bupati, dan Walikota dilakukan dengan demokratis, tetapi di sisi lain adanya keinginan dari para pembentuk undang-undang dasar untuk memberi ruang bagi para pembentuk undang-undang agar mengatur pemilukada lebih lanjut sesuai dengan kondisi keragaman daerah dengan situasi serta kondisi asalkan tidak bertentangan dengan prinsip demokrasi. ${ }^{9}$

Dalam risalah rapat panitia Ad Hoc I, pemikiran dari fraksi PPP yang melatar belakangi dicantumkannya frase "dipilih secara demokratis" antara lain sebagai berikut:

" Gubernur, Bupati dan Walikota dipilih secara langsung oleh rakyat, yang selanjutnya diatur oleh Undang-Undang, hal ini sejalan dengan keinginan kita untuk pemilihan Presiden juga dipilih secara langsung". 10 “... keempat, karena Presiden itu dipilih langsung, maka pada pemerintahan daerah pun Gubernur, Bupati, dan Walikota itu dipilih langsung oleh rakyat". ${ }^{11}$

Merujuk pada risalah rapat tersebut, dapat disimpulkan bahwa latar belakang dan maksud tujuan pembentuk Pasal 18 ayat (4) UUD 1945 adalah Gubernur, Bupati, dan Walikota dipilih secara demokratis adalah sama dengan pemilihan yang dilakukan terhadap Presiden. ${ }^{12}$

9 Sekretariat Jenderal MPR RI," Risalah Rapat Panitia Ad Hoc I (Sidang Tahunan 2000)", Buku kedua jilid 3C, 2000, hlm, 255. Dalam Cakra Arbas, Jalan Terjal Calon Independen pada Pemilukada di Provinsi Aceh, Sofmedia, Jakarta, 2012, hlm. 38.

${ }^{10}$ Ibid.

${ }^{11}$ Risalah Rapat... Ibid., hlm. 272.

${ }^{12}$ Cakra Arbas, Jalan Terjal..., Ibid., hlm. 39. 
Penggunaan frase "dipilih secara demokratis" yang untuk kemudian ditafsirkan pemilukada secara langsung pernah dikuatkan oleh Mahkamah Konstitusi (MK) melalui Putusan No. 072-073/PUU-II/ 2004.

Menurut keterangan saksi Patrialis Akbar dan Lukman Hakim Saifuddin (Panitia Ad Hoc I MPR) yang membahas amandemen Pasal 18 UUD 1945, dalam persidangan judicial review UU No. 32 Tahun 2004 tentang Pemerintahan Daerah menjelaskan bahwa: ${ }^{13}$

"Latar belakang pemikiran rumusan Pasal 18 ayat (4) saat itu adalah bahwa sistem pemilihan yang akan diterapkan disesuaikan dengan perkembangan masyarakat. Masyarakat mempunyai pilihan apakah akan menerapkan sistem perwakilan (pemilihan dilakukan oleh DPRD) atau pemilihan dilakukan secara langsung (pemilihan dilakukan langsung oleh rakyat). Tujuannya adalah agar ada fleksibilitas bagi masyarakat dalam menentukan sistem pemilihan kepala daerah. Hal itu terkait erat dengan penghargaan konstitusi terhadap keragaman adat istiadat dan budaya masyarakat di berbagai daerah yang berbeda-beda. Baik sistem pemilihan secara langsung, maupun sistem pemilihan secara tidak langsung sama-sama masuk pada kategori sistem yang demokratis.berdasarkan 2 (dua) pandangan ini, untuk kemudian disepakati menggunakan frasa "demokratis". Dalam artian karena pada ayat selanjutnya, yakni pada ayat (7) Pasal 18 UUD 1945 menyebutkan susunan dan tata cara penyelenggaraan pemerintahan daerah diatur dalam undang-undang, Undang-undanglah yang nantinya akan menentukan apakah pemilihan kepala daerah itu dilakukan secara langsung oleh rakyat atau sebagaimana sebelumnya dilakukan oleh DPRD, yang terpenting prinsip dasarnya adalah demokratis".

Putusan Mahkamah Konstitusi ini telah menafsirkan frasa 'dipilih secara demokratis" maksudnya adalah memberi kewenangan kepada pembuat UndangUndang untuk mempertimbangkan cara yang tepat dalam Pemilukada. Sekalipun pemilihan secara langsung telah diterapkan untuk memilih Presiden sebagaimana dirumuskan dalam Pasal 6A UUD 1945, hal ini tidak dapat diartikan bahwa pemilukada secara langsung menjadi satu-satunya cara untuk memaknai frasa "dipilih secara demokratis" yang dimuat dalam Pasal 18 ayat (4) UUD 1945.14

\footnotetext{
13 Putusan Mahkamah Konstitusi No. 072-073/PUU-II-2004, hlm. 31.

${ }^{14}$ Ibid., hlm. 38.
} 
Menurut Taufiqurrahman Syahuri ${ }^{15}$ rumusan "dipilih secara demokratis" dalam ketentuan pemilukada juga mempertimbangkan pelaksanaan pemilukada di daerah-daerah yang bersifat khusus dan istimewa sebagaimana yang dimaksud Pasal 18B ayat (1) UUD 1045 yang berbunyi" Negara mengakui dan menghormati satuan-satuan pemerintahan daerah yang bersifat khusus atau bersifat istimewa yang diatur dengan undang-undang".

Menurut Suharizal16 maksud dan tujuan pembentukan Pasal 18 ayat (4) UUD 1945 yang mengatur bahwa Gubernur, Bupati, dan Walikota dipilih secara demokratis adalah tidak harus sama dan dapat juga disamakan dengan pemilihan yang dilakukan terhadap Presiden dan Wakil Presiden. Maka pengertian dipilih secara demokratis dapat ditafsirkan sama dengan tata cara pemilihan yang dilakukan terhadap Presiden dan Wakil Presiden seperti yang tercantum dalam BAB VIIB Pasal 22E UUD 1945 tentang Pemilihan Umum.

Meskipun UUD 1945 hanya menyebut pemilihan kepala daerah dipilih secara demokratis, pembentuk Undang-Undang akhirnya menyejajarkan tata cara pengisian kepala daerah dengan pemilihan presiden dan wakil presiden. Karena itu, makna "dipilih secara demokratis" dipersempit menjadi dipilih secara langsung.

Beberapa pertimbangan penting penyelenggaraan Pilkada langsung adalah sebagai berikut; Pertama, Pilkada langsung merupakan jawaban atas tuntutan aspirasi rakyat karena Presiden dan Wakil Presiden, DPR, DPD, bahkan Kepala Desa selama ini telah dilakukan secara langsung. Tuntutan masyarakat menjadi bagian penting yang harus diakomodasikan untuk memilih sendiri sesuai dengan aspirasinya, seorang kepala daerah yang benar-benar sesuai dan bisa memimpin daerahnya. Kedua, Pilkada langsung merupakan perwujudan UUD 1945. Seperti diamanatkan Pasal 18 ayat (4) UUD 1945, Gubernur, Bupati dan Walikota, masing-masing sebagai kepala pemerintahan daerah provinsi, kabupaten, dan kota dipilih secara demokratis. Ketiga, Pilkada langsung dipandang sebagai sarana pembelajaran demokrasi (politik) bagi rakyat (civics education). Keempat,

15 Taufiqurrahman Syahuri,"anatomi Putusan MK RI tentang Pemilukada",Seminar Putusan MK Pengujian UU No. 32 Tahun 2004 tentang Pemerintahan Daerah, hlm. 6. Dalam Cakra Arbas, Jalan Terjal..., Op. Cit., hlm. 41.

${ }^{16}$ Suharizal, Pemilukada, Dinamika, dan...Op. Cit., hlm. 33. 
Pilkada langsung dipandang sebagai sarana untuk memperkuat otonomi daerah. Keberhasilan otonomi daerah salah satunya ditentukan oleh pemimpin lokal. Semakin baik pemimpin lokal yang dihasilkan melalui Pilkada, maka komitmen pemimpin lokal untuk meningkatkan masyarakat yang menjadi tujuan otonomi daerah dapat diwujudkan. Kelima, Pilkada langsung merupakan sarana penting bagi proses kaderisasi kepemimpinan nasional. ${ }^{17}$

Di era Reformasi ini kita menerapkan pemilihan Presiden dan Kepala Daerah secara langsung oleh rakyat. Pada pemilihan kepala daerah, banyak sekali catatan hitam yang mewarnai proses Pilkada, mulai dari money politics hingga bentrok antar-pendukung yang memakan banyak korban jiwa. Tidak heran jika kini banyak pihak yang menggugat sistem Pilkada agar sistem pemilihan langsung semacam itu ditinjau ulang. Pilkada langsung yang 'mahal' ini bukanlah demokrasi ideal yang kita impikan bersama. Pilkada langsung dengan cara politik uang sebenarnya tidak lebih dari sebuah 'demokrasi teatrikal', pseudo demokrasi atau facade democracy yang tidak banyak manfaatnya karena tidak berkualitas dan tidak banyak bermanfaat untuk perbaikan bangsa ke depan. ${ }^{18}$ Mestinya, ketika demokrasi berjalan pasca-otoritarianisme, maka ia 'harus' dan bahkan 'wajib' memberikan kesejahteraan atau kebaikan bersama dengan serta merta kepada warga masyarakat.

Kecenderungan masyarakat untuk mengapresiasi pelaksanaan pemilukada juga semakin menurun. Dalam berbagai penelitian, ${ }^{19}$ ditemukan fakta mengenai antusiasme masyarakat terhadap proses dan hasil Pemilukada yang cenderung semakin berkurang atau menurun. Meskipun tidak ada ukuran pasti mengenai berapa persen jumlah partisipasi masyarakat agar Pemilukada dikatakan tinggi tetapi fakta penurunan partisipasi masyarakat menunjukkan adanya persoalan dalam penyelenggaraan Pemilukada.

17 Samsul Wahidin, Hukum Pemerintahan Daerah Mengawasi Pemilihan Umum Kepala Daerah, Cetakan 1, Pustaka Pelajar, Yogyakarta, 2008, hlm. 139-141. Lihat juga Morison, Hukum Tata Negara Era Reformasi, Ramdina Prakarsa, Jakarta, 2005, hlm. 199-200.

18 http://www.pewarta-kabarindonesia.blogspot.com. Di akses tanggal 2 Januari 2013.

${ }_{19}$ Moh. Mahfud MD, "Evaluasi Pemilukada Dalam Perspektif Demokrasi dan Hukum” Ceramah Kunci dalam Seminar Nasional Evaluasi Pemilukada: Antara Teori dan Praktik, diselenggarakan oleh Mahkamah Konstitusi pada Rabu-Kamis, 25-26 Januari 2012 di Hotel Sultan Jakarta, hlm. 26. 
Terdapat sekurang-kurangnya 4 (empat) penyebab menurunnya partisipasi masyarakat dalam Pemilukada. Pertama,20 masyarakat secara sadar memang tidak mau menggunakan hak pilihnya karena dilandasi oleh sikap apatis. Bagi mereka, menggunakan atau tidak menggunakan hak suara dalam Pemilukada maknanya sama: tidak memberi pengaruh signifikan dalam keseharian hidup. Kedua, Daftar Pemilih Tetap (DPT) yang amburadul dan tidak akurat berkontribusi besar melemahkan semangat masyarakat yang semula berniat untuk berpartisipasi. Ketiga, masyarakat pemilih cenderung lebih mendahulukan kebutuhan individualnya, seperti bekerja, berladang, merantau atau sekolah ketimbang hadir ke TPS untuk menggunakan hak pilihnya. Keempat, partisipasi dalam pemilukada didorong semangat pragmatisme masyarakat. Kalau ada kandidat yang memberi keuntungan mereka mau berpartisipasi, kalau tidak maka tidak perlu berpartisipasi.

Menyikapi pelaksanaan pemilihan Kepala Daerah (Pilkada) langsung yang semakin banyak mendapat sorotan dari berbagai kalangan, kini DPR berupaya merevisi undang-undang pilkada dan mencari masukan ke berbagai daerah. Isu utama yang berkembang adalah banyaknya dampak negatif Pilkada langsung, antara lain politik uang, konflik sosial, dan keberpihakan penyelenggara. Akhirnya, Pilkada langsung menghasilkan kepala daerah yang korup dan pemerintah bayangan (shadow government) oleh tim sukses, yang justru lebih berkuasa. Lalu timbul pertanyaan, apa yang salah dari Pilkada langsung? Apakah budaya politiknya, desain, atau teknis penyelenggaraan? Pilkada langsung diadopsi dari masyarakat yang menerapkan demokrasi liberal yang mensyaratkan adanya kebebasan memilih. Memilih adalah hak individu, bukan kewajiban. Pilkada langsung bersifat kompetitif dan fair. Apakah kondisi masyarakat kita memenuhi persyaratan itu?21

Sedangkan Nahdlatul Ulama (NU) menilai pemilihan kepala daerah secara langsung sebagai hasil reformasi yang diharapkan membawa kebaikan ternyata

20 Ibid.

${ }^{21}$ http://www.metro7.co.id . Solusi Pilkada Langsung.html. Di akses 3 Januari 2013. Ada banyak masalah yang bisa diidentifikasi selama proses pemilihan kepala daerah, selengkapnya baca Leo Agustina, Pilkada dan Dinamika Politik Lokal, Cetakan I, Pustaka Pelajar, Yogyakarta, 2009, hlm. 121-152. 
di dalam praktiknya banyak menimbulkan kerusakan sehingga patut dipertimbangkan untuk dihentikan.22

Untuk itu, Musyawarah Nasional (Munas) Alim Ulama dan Konferensi Besar (Konbes) Nahdlatul Ulama (NU) merekomendasikan penghapusan pilkada langsung, baik untuk memilih Gubernur maupun Bupati/Wali Kota. Rekomendasi tersebut merupakan hasil sidang Komisi B atau Bahtsul Masail Ad-Diniyah Maudlu'iyyah yang dipimpin oleh KH Hartami Hasni di Pondok Pesantren Kempek, Kecamatan Gempol, Kabupaten Cirebon, Jawa Barat. Dengan hasil pembahasan ini, NU secara resmi akan merekomendasikan agar pilkada kembali dilaksanakan secara tidak langsung melalui DPRD. ${ }^{23}$

NU berpendapat agar pilkada langsung ditinjau ulang, dan kembali ke pilkada tidak langsung oleh DPRD. Selain pilkada langsung tidak sesuai dengan Pancasila, kerugian yang ditimbulkan jauh lebih besar dibandingkan dengan kemaslahatan yang diperoleh. Melalui pilkada langsung diharapkan terpilih pemimpin yang aspiratif dan lebih bisa menyejahterakan rakyat. Namun, fakta di lapangan menunjukkan pilkada langsung justru menimbulkan banyak kerugian seperti maraknya politik uang yang merusak moral, menyedot biaya besar, dan menimbulkan konflik horizontal. Jadi kemaslahatan yang diharapkan dari pilkada langsung masih angan-angan, sementara kerugian yang ditimbulkan sudah terbukti. ${ }^{24}$

Tetapi, reaksi terhadap wacana pemilihan kepala daerah oleh DPRD terus bermunculan. Di antaranya adalah, Direktur Eksekutif Perkumpulan untuk Pemilu dan Demokrasi (Perludem) Titi Anggraini mengatakan bahwa, wacana tersebut adalah wacana yang mengingkari semangat dan tujuan besar proses demokratisasi di Indonesia, yaitu meningkatkan keterlibatan dan partisipasi masyarakat sebesar-besarnya, menguatkan transparansi proses politik dan ketatanegaraan. Alasan mahalnya ongkos politik penyelenggaraan pemilukada adalah alasan yang tidak bisa menjustifikasi pemilihan gubernur oleh DPRD. Belum ada penelitian ilmiah yang bisa memastikan bahwa biaya pemilihan

${ }^{22}$ Faizal Rizki http://www.aktual.co/politik. Nu menilai pilkada langsung lebih baik ditiadakan., diakses 4 Januari 2013.

${ }^{23}$ http://www.seputar-indonesia.com. Diakses 7 Januari 2013.

${ }^{24}$ Ibid. 
gubernur oleh DPRD jauh lebih efisien dari pada pemilukada langsung. Tidak ada yang bisa menjamin bahwa ongkos politik 'tidak resmi' untuk 'membeli perahu' partai di DPRD jauh lebih sedikit ketimbang penyelenggaraan pemilihan langsung oleh rakyat. ${ }^{25}$

Sistem yang dihasilkan era reformasi ini terbukti menimbulkan kerusakan dan patut untuk dihentikan. Pendidikan politik dan demokrasi yang diperoleh masyarakat bukanlah pendidikan yang baik dan bermoral, melainkan justru pendidikan yang tidak sehat, dimana pemilihan langsung diharapkan memunculkan pemimpin-pemimpin yang berkualitas namun kenyataannya malah sebaliknya, karena sistem ini memunculkan cara-cara kapitalis yang transaksional sehingga tidak akan terjadi hubungan yang sinergis antara Rakyat dengan Pemimpin. Pemimpin yang dihasilkan oleh sistem pemilihan secara langsung tidak akan bertanggung jawab terhadap rakyat karena mereka merasa telah membeli suara Rakyat dan rakyat tidak bisa melakukan kontrol sosial karena mereka sudah menggadaikan idealisme nya, kondisi ini sangat bahaya bagi kehidupan berbangsa dan bernegara. Pemilihan secara langsung banyak menimbulkan "kemadlorotan" atau kerugian di dalam pelaksanaannya seperti konflik sosial, memecah belah kerukunan keluarga, mengakibatkan suap dan berujung korupsi, sehingga tanpa mengurangi arti demokrasi, Pemilihan langsung sudah saatnya dihentikan dan pimpinan daerah dipilih para wakil rakyat, dengan demikian rakyat bisa bekerja lebih produktif tanpa disibukkan oleh pemilihan langsung yang banyak memakan korban dan jelas-jelas bertentangan dengan demokrasi Pancasila. ${ }^{26}$

Meskipun Pemilukada langsung banyak mendapat kritikan dari berbagai pihak, UU No. 1 Tahun 2015 tentang Pemilihan Gubernur, Bupati, dan Walikota, tetap menggunakan sistem pemilihan secara langsung untuk memilih Gubernur, Bupati, dan Walikota.

${ }^{25}$ http://news.detik.com.langkah mundur jika pemilihan kepala daerah kembali ke tangan dprd. Diakses 10 Januari 2013.

${ }^{26}$ Ibid. 


\section{Keterangan Saksi}

Dalam putusan tersebut dapat kita simak beberapa keterangan ahli dari pemohon antara lain Hamdi Muluk mengatakan sebagai berikut:27

“...Dengan sistem pemilihan presiden yang term pemilihannya harus menunggu dulu hasil pemilihan anggota legislatif, dan bahkan syarat pengusungan presiden diberi ambang batas (presidential threshold) oleh partai atau gabungan partai politik, maka sebenarnya presiden yang maju sudah tersandera oleh koalisi partai pengusungnya. Dalam konteks sistem multipartai di Indonesia, maka koalisi pengusung presiden sudah sejak awal sangat ditentukan oleh politik "dagang sapi" (transaksional) yang membuat biaya pengusungan presiden menjadi sangat mahal, dan harga ini harus dibayar oleh presiden ketika dia terpilih dengan tidak mengutamakan kepentingan rakyat (mendukung kepentingan koalisi partai pendukung beserta "cukong" nya). jika pemilihan presiden didahulukan, baru setelah itu pemilihan anggota legislatif, maka presiden tidak tersandera oleh koalisi politik. Atau yang terbaik diserentakkan saja, maka banyak keuntungan yang akan didapat dari disain yang seperti ini, terutama dari segi psikologi politik. Pertama. dengan cara ini partai politik akan sungguh-sungguh mempersiapkan paket yang menarik antara presiden dan susunan anggota legislatif dalam satu paket pemilihan. Kondisi ini jauh lebih ideal bagi partai-partai untuk secara sungguh-sungguh mengedepankan ideologi dan platform partai, serta menghilangkan peluang kompromi (politik dagang sapi) ideologi politik demi sebuah koalisi mengusung presiden. Kondisi straigth ticket akan didapat kalau memang partai politik serius mendekatkan presiden dan platform partai, beserta susunan anggota legislatif dalam suatu paket dan waktu yang bersamaan. Kedua. pemilihan serentak, apalagi digabungkan juga dengan pemilihan kepala daerah akan mengurangi kelelahan psikologis (psychologicalfatigue) para pemilih, yang terus menerus dalam waktu beberapa bulan harus kembali ke bilik suara. Pemilihan yang terlalu sering akan membuat rakyat bingung, capek, dan menurun motivasinya untuk ikut pemilihan umum. Pemilu serentak dalam beberapa studi (misal lihat Csaba Nikolenyi, Political Studies, Volume 58, Issues 1, Februari 2010) berhasil menaikkan partisipasi politik (voter turn-out). Sudah selayaknya Indonesia memulai usaha penyerentakan pemilu dimulai tahun-tahun terdekat ini. Paling tidak beberapa alasan diatas inilah yang bisa kita pakai untuk memperkuat argumen urgensi diadakannya pemilu serentak.

Saksi ahli lainnya yaitu Didik Supriyanto menyampaikan kesaksiannya sebagai berikut: 28

“...Solusi Taktis. Penyelenggaraan pemilu serentak, atau pemilu serentak nasional (memilih anggota DPR, DPD serta presiden dan wakil presiden) dan

\footnotetext{
${ }^{27}$ http://news.detik.com.langkah mundur jika pemilihan..., Op. Cit., hlm. 39-40.

28 Ibid., hlm. 44-48.
} 
pemilu serentak daerah (memilih DPRD serta kepala daerah dan wakil kepala daerah), dapat mengatasi kompleksitas penyelenggaraan pemilu. Pemilih menghadapi lebih sedikit peserta pemilu dan calon sehingga memungkinkan mereka bersikap rasional. Partai politik lebih mudah menyiapkan calon anggota leglslatif, juga lebih mudah mengendalikan konflik internal yang dlakibatkan pengajuan pasangan calon presiden dan pasangan calon kepala daerah. Kader-kader partai juga mempunyai waktu kompetisi lebih Intesif karena terdapat dua kali pemilu dalam kurun lima tahun. Penyelenggara pemilu lebih mudah mengelola penyelenggaraan pemilu karena beban pekerjaan pemilu menjadi lebih ringan pada satu momen pemilu, dan lebih seimbang antarpemilu dalam periode lima tahunan. Dari sisi anggaran terjadi penghematan dana negara yang luar biasa, karena pembayaran honor petugas pemilu hanya dua kali saja.

Solusi Strategis. Penyelenggaraan pemilu serentak, atau pemilu serentak nasional (memilih anggota DPR, DPD serta presiden dan wakil preslden) dan pemilu serentak daerah (memilih DPRD serta kepala daerah dan wakil kepala daerah), dapat mengatasi dampak politik pascapemilu. Pertama, pemilu serentak akan menciptakan coattail effect sehingga calon pejabat eksekutif terpilih akan mendapat dukungan mayoritas parlemen. Partai atau koalisi partai pendukung pemerintah akan solid karena mereka bersama-sama berjuang untuk memenangkan pemilu. Selain itu, partai-partai politik mempunyai waktu cukup lama untuk membangun koalisi, mereka bisa merumuskan platform politik yang menjadi panduan berkuasa, dan membagi bagi kursi kekuasaan secara lebih sehat. Hal yang sama juga terjadi dalam dalam pemilu kepala daerah. Jikapun terjadi politik transaksional antara pejabat eksekutif dengan anggota legislatif, lokasinya bisa dipersempit pada partai-partai koalisi pendukung pemerintah. Namun bukan berarti mereka bisa berbuat apa saja, sebab partai-partai yang calonnya kalah, secara otomatis akan menjadi oposisi. Partai-partai oposisi dipaksa bekerja keras untuk mengkritisi kebijakan pemerintah dan memberikan alternatif, sebab jika tidak mereka tetap akan kalah dalam pemilu berikutnya. Kedua, pemilu serentak nasional yang disusul pemilu serentak daerah dua atau tiga tahun beriktunya, membuat pemilih bisa secara efektif menjatuhkan sanksi kepada partai politik yang kinerjanya buruk. Sebab jika pemenang pemilu serentak nasional kinerjanya buruk, maka pemilih akan cenderung menghukum mereka pada saat pemilu serentak daerah, atau sebaliknya. Pemisahan pemilu serentak nasional dengan pemilu serentak daerah memudahkan pemilih untuk besikap rasional dalam memberikan suara, karena pada saat pemilu serentak daerah mereka tidak dipengaruhi oleh kampanye pemilu serentak nasional, demikian juga sebaliknya. Partai politik dan kader-kader partai politik juga terdorong untuk bekerja keras, karena mereka mempunyai kesempatan dua kali dalam kurun lima tahun untuk berkompetisi dalam pemilu.

Tidak Melanggar Konstitusi. Memperhatikan Pasal 6A ayat (2) UUD 1945, bahwa Pasangan caion Presiden dan Wakil Presiden diusulkan oleh partai politik atau gabungan partai politik peserta pemilihan umum sebelum pelaksanaan pemilihan umum, bukan berarti bahwa pemilu legislatif harus berjalan lebih dahulu baru 
kemudian pemilu Presiden. Karena pengertian "peserta pemilihan umum sebelum pelaksanaan pemilihan umum," berarti pemilu sebelumnya, bukan terbatas pada pemilu legislatif sebelumnya. Dengan demikian menyatukan pemilu DPR, DPD dan pemilu presiden, tidak melanggar konstitusi karena pasangan calon presiden bisa diajukan oleh peserta pemilu lima tahun sebelumnya. Konstitusi juga tidak melarang penyatuan pemilu DPRD dengan pemilu kepala daerah. Konstitusi hanya menegaskan bahwa anggota DPRD dipilih melalui pemilu yang diselenggarakan setiap lima tahun, sedang terhadap kepala daerah dikatakan bahwa mereka dipilih secara demokratis.

Sedangkan Saldi Isra memberikan kesaksiannya secara tertulis sebagai berikut:29

“... memisahkan waktu penyelenggaraan pemilu legislatif dengan pemilu presiden/wakil presiden untuk membenarkan presidential threshold adalah bentuk pengingkaran terhadap kesempatan bagi semua partai politik peserta pemilihan umum sebagaimana termaktub dalam Pasal 6A ayat (1) UUD 1945. Dalam pengertian ini, kekhawatiran munculnya calon presiden/wakil presiden dalam jumlah yang lebih banyak (sesuai dengan jumlah partai politik peserta pemilu) adalah kekhwatiran yang tidak paham dengan konsekuensi pemilihan langsung. Bahkan, kalaupun calon hadir dalam jumlah yang banyak, Pasal 6A ayat (4) UUD 1945 telah mengantisipasi dengan membuka kemungkinan adanya putaran kedua (second round). Oleh karena itu, basis argumentasi menggunakan hasil pemilu legislatif sebagai dasar perhitungan ambang batas untuk mengajukan pasangan calon presiden dengan cara memisahkan waktu penyelenggaran pemilu legislatif dan pemilu presiden/wakil presiden jelas merusak logika sistem presidensial. Tidak hanya itu, pemisahan jadwal tersebut untuk membenarkan hadirnya ambang batas jelas-jelas bertentangan dengan ketentuan Pasal 22E ayat (1) UUD 1945 alias pilihan yang inkonstitusional. Melacak sikap dari beberapa partai politik besar di DPR dan sekaligus keinginan mereka untuk mempertahankan jadwal penyelenggaran pemilu yang terpisah, sulit berharap para pembentuk undang-undang untuk mengembalikan makna hakiki Pasal 22E ayat (1) UUD 1945. Oleh karena itu, agar proses pemilu semakin hari tidak makin menjauh dari semangat konstitusi, jalan satu-satunya Mahkamah Konstitusi harus menyatakan pemisahan jadwal penyelenggaraan pemilu legisatif dengan pemilu presiden/wakil presiden inkonstitusional alias tidak memiliki kekuatan mengikat. Jika ini dilakukan Mahkamah Konstitusi, kita tidak perlu lagi berhabis hari berdebat soal presidential threshold.

Dalam putusan tersebut Mahkamah Konstitusi memberikan tiga dasar pertimbangan sebagai berikut: ${ }^{30}$

\footnotetext{
${ }^{29}$ Ibid., hlm. 49-50.

${ }^{30}$ Ibid., hlm. 78-84.
} 
"Pertama, menurut Mahkamah penyelenggaraan Pilpres haruslah dikaitkan dengan rancang bangun sistem pemerintahan menurut UUD 1945, yaitu sistem pemerintahan presidensial. Salah satu di antara kesepakatan Badan Pekerja Majelis Permusyawaratan Rakyat saat melakukan pembahasan Perubahan UUD 1945 (1999-2002) adalah memperkuat sistem presidensial. Dalam sistem pemerintahan presidensial menurut UUD 1945, Presiden memegang kekuasaan pemerintahan menurut Undang-Undang Dasar. Presiden sebagai kepala Negara dan lambang pemersatu bangsa. Presiden tidak hanya ditentukan oleh mayoritas suara pemilih, akan tetapi juga syarat dukungan minimal sekurang-kurangnya lima puluh persen suara di setiap provinsi yang tersebar di lebih dari setengah jumlah provinsi di Indonesia dapat langsung diambil sumpahnya sebagai Presiden. Presiden mengangkat dan memberhentikan menteri-menteri negara. Presiden dipilih langsung oleh rakyat untuk masa jabatan lima tahun dan sesudahnya dapat dipilih kembali dalam jabatan yang sama hanya untuk satu kali masa jabatan. Presiden hanya dapat diberhentikan dalam masa jabatannya oleh Majelis Permusyawaratan Rakyat (MPR) atas usul Dewan Perwakilan Rakyat (DPR) hanya dengan alasan-alasan tertentu yang secara limitatif ditentukan dalam UUD 1945, yaitu apabila terbukti menurut putusan pengadilan dalam hal ini Mahkamah Konstitusi, telah melakukan pelanggaran hukum berupa pengkhianatan terhadap negara, korupsi, penyuapan, tindak pidana berat lainnya, atau perbuatan tercela dan/atau apabila terbukti tidak lagi memenuhi syarat sebagai Presiden. Dengan sistem pemerintahan yang demikian, UUD 1945 menempatkan Presiden dalam posisi yang kuat sehingga dalam masa jabatannya tidak dapat dijatuhkan oleh DPR selain karena alasan dan proses yang secara limitatif telah ditentukan dalam UUD 1945. Posisi Presiden dalam hubungannya dengan DPR adalah sejajar dengan prinsip hubungan yang saling mengawasi dan mengimbangi (checks and balances). Menurut UUD 1945, dalam hal tertentu kebijakan Presiden harus memperhatikan pertimbangan DPR seperti pengangkatan duta dan penerimaan duta dari negara lain. Presiden dalam menyatakan perang, membuat perdamaian dan perjanjian dengan negara lain, serta perjanjian internasional yang menimbulkan akibat luas dan mendasar bagi kehidupan rakyat yang terkait dengan beban keuangan negara dan/atau mengharuskan perubahan atau pembentukan Undang-Undang harus dengan persetujuan DPR. Pada sisi lain, DPR dalam menjalankan kekuasaan membentuk Undang-Undang harus dilakukan bersamasama serta disetujui bersama dengan Presiden. Mengenai Anggaran Pendapatan dan Belanja Negara (APBN), Presiden mengajukan rancangan APBN untuk dibahas bersama untuk mendapat persetujuan DPR dan apabila rancangan APBN tidak mendapatkan persetujuan DPR, Presiden menjalankan APBN tahun sebelumnya. Berdasarkan sistem pemerintahan yang demikian, posisi Presiden secara umum tidak tergantung pada ada atau tidak adanya dukungan DPR sebagaimana lazimnya yang berlaku dalam sistem pemerintahan parlementer. Hanya untuk tindakan dan beberapa kebijakan tertentu saja tindakan Presiden harus dengan pertimbangan atau persetujuan DPR. Walaupun dukungan DPR sangat penting untuk efektivitas jalannya 
pemerintahan yang dilakukan Presiden tetapi dukungan tersebut tidaklah mutlak. Menurut UUD 1945, seluruh anggota DPR dipilih melalui mekanisme pemilihan umum yang pesertanya diikuti oleh partai politik, sehingga anggota DPR pasti anggota partai politik. Oleh karena konfigurasi kekuatan DPR, berkaitan dengan konfigurasi kekuatan partai politik yang memiliki anggota di DPR, maka posisi partai politik yang memiliki kursi di DPR dalam sistem pemerintahan Indonesia adalah penting dan dapat mempengaruhi efektivitas pelaksanaan kebijakan pemerintahan oleh Presiden. Walaupun demikian, Presiden dalam menjalankan kekuasaan pemerintahan tidak tergantung sepenuhnya pada ada atau tidak adanya dukungan partai politik, karena Presiden dipilih langsung oleh rakyat, maka dukungan dan legitimasi rakyat itulah yang seharusnya menentukan efektivitas kebijakan pemerintahan yang dilakukan oleh Presiden. Dari ketentuan UUD 1945 tersebut, dapat disimpulkan bahwa pada satu sisi, sistem pemerintahan Indonesia menempatkan partai politik dalam posisi penting dan strategis, yaitu Presiden memerlukan dukungan partai politik yang memiliki anggota di DPR untuk efektivitas penyelenggaraan pemerintahannya dan pada sisi lain menempatkan rakyat dalam posisi yang menentukan legitimasi seorang Presiden. Di samping itu, pada satu sisi calon Presiden/Wakil Presiden hanya dapat diajukan oleh partai politik atau gabungan partai politik dan pada sisi lain menempatkan rakyat dalam posisi yang menentukan karena siapa yang menjadi Presiden sangat tergantung pada pilihan rakyat. Hak eksklusif partai politik dalam pencalonan Presiden sangat terkait dengan hubungan antara DPR dan Presiden dan rancang bangun sistem pemerintahan yang diuraikan di atas, karena anggota DPR seluruhnya berasal dari partai politik, akan tetapi hak eksklusif partai politik ini diimbangi oleh hak rakyat dalam menentukan siapa yang terpilih menjadi Presiden dan legitimasi rakyat kepada seorang Presiden. Dengan demikian, idealnya menurut desain UUD 1945, efektivitas penyelenggaraan pemerintahan oleh Presiden sangat berkaitan dengan dua dukungan, yaitu dukungan rakyat pada satu sisi dan dukungan partai politik pada sisi yang lain. Hal yang sangat mungkin terjadi adalah pada satu sisi Presiden mengalami kekurangan (defisit) dukungan partai politik yang memiliki anggota DPR, tetapi pada sisi lain mendapat banyak dukungan dan legitimasi kuat dari rakyat. Dalam kondisi yang demikian, terdapat dua kemungkinan yang akan terjadi, yaitu pertama, sepanjang tidak ada pelanggaran yang ditentukan oleh UUD 1945 oleh Presiden yang dapat digunakan sebagai alasan pemakzulan, Presiden tetap dapat menjalankan pemerintahan tanpa dapat dijatuhkan oleh DPR walaupun tidak dapat melaksanakan pemerintahannya secara efektif. Kemungkinan kedua, adalah DPR akan mengikuti kemauan Presiden, karena jika tidak, partai-partai politik akan kehilangan dukungan rakyat dalam pemilihan umum. Berdasarkan kerangka sistem yang demikian, menurut Mahkamah, mekanisme pemilihan Presiden dalam desain UUD 1945 harus dikaitkan dengan sistem pemerintahan yang dianut UUD 1945. Dalam penyelenggaraan Pilpres tahun 2004 dan tahun 2009 yang dilakukan setelah Pemilu Anggota Lembaga Perwakilan ditemukan fakta politik bahwa untuk mendapat dukungan demi keterpilihan sebagai 
Presiden dan dukungan DPR dalam penyelenggaraan pemerintahan, jika terpilih, calon Presiden terpaksa harus melakukan negosiasi dan tawarmenawar (bargaining) politik terlebih dahulu dengan partai politik yang berakibat sangat mempengaruhi jalannya roda pemerintahan di kemudian hari. Negosiasi dan tawar-menawar tersebut pada kenyataannya lebih banyak bersifat taktis dan sesaat daripada bersifat strategis dan jangka panjang, misalnya karena persamaan garis perjuangan partai politik jangka panjang. Oleh karena itu, Presiden pada faktanya menjadi sangat tergantung pada partai-partai politik yang menurut Mahkamah dapat mereduksi posisi Presiden dalam menjalankan kekuasaan pemerintahan menurut sistem pemerintahan presidensial. Dengan demikian, menurut Mahkamah, penyelenggaraan Pilpres harus menghindari terjadinya negosiasi dan tawar menawar (bargaining) politik yang bersifat taktis demi kepentingan sesaat, sehingga tercipta negosiasi dan koalisi strategis partai politik untuk kepentingan jangka panjang. Hal demikian akan lebih memungkinkan bagi penggabungan partai politik secara alamiah dan strategis sehingga dalam jangka panjang akan lebih menjamin penyederhanaan partai politik. Dalam kerangka itulah ketentuan Pasal 6A ayat (2) UUD 1945 harus dimaknai. Menurut Mahkamah, praktik ketatanegaraan hingga saat ini, dengan pelaksanaan Pilpres setelah Pemilu Anggota Lembaga Perwakilan ternyata dalam perkembangannya tidak mampu menjadi alat transformasi perubahan sosial ke arah yang dikehendaki. Hasil dari pelaksanaan Pilpres setelah Pemilu Anggota Lembaga Perwakilan tidak juga memperkuat sistem presidensial yang hendak dibangun berdasarkan konstitusi. Mekanisme saling mengawasi dan mengimbangi (checks and balances), terutama antara DPR dan Presiden tidak berjalan dengan baik. Pasangan Calon Presiden dan Wakil Presiden kerap menciptakan koalisi taktis yang bersifat sesaat dengan partai-partai politik sehingga tidak melahirkan koalisi jangka panjang yang dapat melahirkan penyederhanaan partai politik secara alamiah. Dalam praktiknya, model koalisi yang dibangun antara partai politik dan/atau dengan pasangan calon Presiden/Wakil Presiden justru tidak memperkuat sistem pemerintahan presidensial. Pengusulan Pasangan Calon Presiden dan Wakil Presiden oleh gabungan partai politik tidak lantas membentuk koalisi permanen dari partai politik atau gabungan partai politik yang kemudian akan menyederhanakan sistem kepartaian. Berdasarkan pengalaman praktik ketatanegaraan tersebut, pelaksanaan Pilpres setelah Pemilu Anggota Lembaga Perwakilan tidak memberi penguatan atas sistem pemerintahan yang dikehendaki oleh konstitusi. Oleh karena itu, norma pelaksanaan Pilpres yang dilakukan setelah Pemilu Anggota Lembaga Perwakilan telah nyata tidak sesuai dengan semangat yang dikandung oleh UUD 1945 dan tidak sesuai dengan makna pemilihan umum yang dimaksud oleh UUD 1945, khususnya dalam Pasal 22E ayat (1) UUD 1945 yang menyatakan, "Pemilihan umum dilaksanakan secara langsung, umum,bebas, rahasia, jujur, dan adil setiap lima tahun sekali" dan Pasal 22E ayat (2) UUD 1945 yang menyatakan, "Pemilihan umum diselenggarakan untuk memilih anggota Dewan Perwakilan Rakyat, Dewan Perwakilan Daerah, Presiden dan Wakil Presiden dan Dewan Perwakilan Rakyat Daerah", serta Pasal 1 
ayat (2) UUD 1945 yang menyatakan, "Kedaulatan berada di tangan rakyat dan dilaksanakan menurut Undang-Undang Dasar".

Kedua, dari sisi original intent dan penafsiran sistematik. Apabila diteliti lebih lanjut makna asli yang dikehendaki oleh para perumus perubahan UUD 1945, dapat disimpulkan bahwa penyelenggaraan Pilpres adalah dilakukan serentak dengan Pemilu Anggota Lembaga Perwakilan. Hal itu secara tegas dikemukakan oleh Slamet Effendy Yusuf sebagai salah satu anggota Panitia Ad Hoc I Badan Pekerja MPR RI yang mempersiapkan draft perubahan UUD 1945 yang mengemukakan bahwa para anggota MPR yang bertugas membahas perubahan UUD 1945 ketika membicarakan mengenai permasalahan ini telah mencapai satu kesepakatan bahwa "...yang dimaksud pemilu itu adalah pemilu untuk DPR, pemilu untuk DPD, pemilu untuk presiden dan wakil presiden, dan DPRD. Jadi, diletakkan dalam satu rezim pemilu." Diterangkan lebih lanjut secara teknis bahwa gambaran pelaksanaan Pemilu nantinya akan terdapat 5 (lima) kotak, yaitu "... Kotak 1 adalah kotak DPR, kotak 2 adalah kotak DPD, kotak 3 adalah presiden dan wakil presiden, dan kotak 4 adalah DPRD provinsi, kotak 5 adalah DPRD kabupaten/kota." (vide Naskah Komprehensif Perubahan Undang-Undang Dasar Negara Republik Indonesia Tahun 1945, Latar Belakang, Proses, dan Hasil Pembahasan 1999-2002, Buku V Pemilihan Umum (2010), halaman 602 yang mengutip Risalah Komisi A ke-2 Sidang Majelis pada Sidang Tahunan MPR 2001, 5 November 2001). Dengan demikian, dari sudut pandang original intent dari penyusun perubahan UUD 1945 telah terdapat gambaran visioner mengenai mekanisme penyelenggaraan Pilpres, bahwa Pilpres diselenggarakan secara bersamaan dengan Pemilu Anggota Lembaga Perwakilan. Hal demikian sejalan dengan Pasal 22E ayat (2) UUD 1945 yang menentukan bahwa yang dimaksud dengan pemilihan umum berada dalam satu tarikan nafas, yakni, "Pemilihan umum diselenggarakan untuk memilih anggota Dewan Perwakilan Rakyat, Dewan Perwakilan Daerah, Presiden dan Wakil Presiden dan Dewan Perwakilan Rakyat Daerah". Berdasarkan pemahaman yang demikian, UUD 1945 memang tidak memisahkan penyelenggaraan Pemilu Anggota Lembaga Perwakilan dan Pilpres. Terkait dengan hal tersebut, pemilihan umum yang dimaksud frasa "sebelum pelaksanaan pemilihan umum" dalam Pasal 6A ayat (2) UUD 1945 yang selengkapnya menyatakan, "Pasangan calon Presiden dan Wakil Presiden diusulkan oleh partai politik atau gabungan partai politik peserta pemilihan umum sebelum pelaksanaan pemilihan umum" adalah pemilihan umum sebagaimana dimaksud dalam Pasal 22E ayat (2) UUD 1945. Maksud penyusun perubahan UUD 1945 dalam rumusan Pasal 6A ayat (2) UUD 1945 pada kenyataannya adalah agar pelaksanaan pemilihan umum diselenggarakan secara bersamaan antara Pemilu untuk memilih anggota Dewan Perwakilan Rakyat, Dewan Perwakilan Daerah, dan Dewan Perwakilan Rakyat Daerah (Pemilu Anggota Lembaga Perwakilan) dan Pemilu untuk memilih Presiden dan Wakil Presiden (Pilpres). Selain itu, dengan mempergunakan penafsiran sistematis atas ketentuan Pasal 6A ayat (2) UUD 1945 yang menyatakan, "Pasangan calon Presiden dan Wakil Presiden diusulkan oleh partai politik atau gabungan partai politik peserta pemilihan umum sebelum pelaksanaan pemilihan umum", dikaitkan dengan Pasal 22E ayat (2) UUD 1945 
yang menyatakan, "Pemilihan umum diselenggarakan untuk memilih anggota Dewan Perwakilan Rakyat, Dewan Perwakilan Daerah, Presiden dan Wakil Presiden dan Dewan Perwakilan Rakyat Daerah", adalah tidak mungkin yang dimaksud "sebelum pemilihan umum" dalam Pasal 6A ayat (2) UUD 1945 adalah sebelum Pilpres, karena jika frasa "sebelum pemilihan umum" dimaknai sebelum Pilpres, maka frasa "sebelum pemilihan umum" tersebut menjadi tidak diperlukan, karena calon Presiden dengan sendirinya memang harus diajukan sebelum pemilihan Presiden. Dengan demikian menurut Mahkamah, baik dari sisi metode penafsiran original intent maupun penafsiran sistematis dan penafsiran gramatikal secara komprehensif, Pilpres dilaksanakan bersamaan dengan pemilihan umum untuk memilih anggota lembaga perwakilan. Menurut Mahkamah, dalam memaknai ketentuan UUD mengenai struktur ketatanegaraan dan sistem pemerintahan harus mempergunakan metode penafsiran yang komprehensif untuk memahami norma UUD 1945 untuk menghindari penafsiran yang terlalu luas, karena menyangkut desain sistem pemerintahan dan ketatanegaraan yang dikehendaki dalam keseluruhan norma UUD 1945 sebagai konstitusi yang tertulis.

Ketiga, sejalan dengan pemikiran di atas, penyelenggaraan Pilpres dan Pemilu Anggota Lembaga Perwakilan secara serentak memang akan lebih efisien, sehingga pembiayaan penyelenggaraan lebih menghemat uang negara yang berasal dari pembayar pajak dan hasil eksploitasi sumber daya alam serta sumber daya ekonomi lainnya. Hal itu akan meningkatkan kemampuan negara untuk mencapai tujuan negara sebagaimana diamanatkan dalam Pembukaan UUD 1945 yang antara lain untuk memajukan kesejahteraan umum dan sebesar-besarnya kemakmuran rakyat. Selain itu, Pilpres yang diselenggarakan secara serentak dengan Pemilu Anggota Lembaga Perwakilan juga akan mengurangi pemborosan waktu dan mengurangi konflik atau gesekan horizontal di masyarakat; Bahwa selain itu, hak warga negara untuk memilih secara cerdas pada pemilihan umum serentak ini terkait dengan hak warga negara untuk membangun peta checks and balances dari pemerintahan presidensial dengan keyakinannya sendiri. Untuk itu warga negara dapat mempertimbangkan sendiri mengenai penggunaan pilihan untuk memilih anggota DPR dan DPRD yang berasal dari partai yang sama dengan calon presiden dan wakil presiden. Hanya dengan pemilihan umum serentak warga negara dapat menggunakan haknya untuk memilih secara cerdas dan efisien. Dengan demikian pelaksanaan Pilpres dan Pemilihan Anggota Lembaga Perwakilan yang tidak serentak tidak sejalan dengan prinsip konstitusi yang menghendaki adanya efisiensi dalam penyelenggaraan pemerintahan dan hak warga negara untuk memilih secara cerdas".

Putusan MK sebagaimana diuraikan di atas sama sekali tidak menyinggung pemilihan kepala daerah seperti pemilihan gubernur, walikota dan bupati. Ketua Perkumpulan untuk Pemilu dan Demokrasi (Perludem), Didik Supriyadi, menuturkan, akan jauh lebih hemat lagi jika Pemilukada juga serentak. 
Serentaknya penyelenggaraan pemilu baik tingkat nasional dan daerah, akan menyisakan dua kali pemilu saja dalam kurun waktu lima tahun. Pertama untuk memilih presiden, wapres, DPD dan DPR. Kedua memilih kepala daerah dan DPRD di tahun ketiga. Dengan begitu, ada pemerintahan berkesinambungan. ${ }^{31}$

Jika mau berpikir komprehensif, dalam memutus penyelenggaraan pemilu serentak, MK seharusnya mempertimbangkan posisi penyelenggaraan pilkada. Mengingat banyak putusan MK yang membahas soal ini. Jika Pemilukada serentak diterapkan maka akan menciptakan keuntungan yang lebih besar. Antara lain menghemat biaya, mengurangi beban penyelenggaraan, dan memudahkan pemilih bersikap rasional. ${ }^{32}$

\section{Pemilihan Kepala Daerah Serentak}

Penyelenggaraan pemilu serentak yang akan berlangsung di 2019 dinilai dapat mempengaruhi Pemilukada. MK seharusnya mempertimbangkan hal tersebut sebab banyak putusan dari lembaga itu membahas soal sengketa Pemilukada. Ketua Perludem, Didik Supriyanto mengatakan, MK memang menetapkan Pemilukada tidak bisa dianggap bagian dari pemilu. Padahal berdasarkan tafsir mereka pada Pasal 18 ayat (4) UUD 1945, kepala daerah dipilih secara demokratis. Sedangkan ada dua masalah Pemilukada yang selalu dikeluhkan, pertama pelaksanaan yang tidak terkontrol. Kedua, menjadikan hubungan kepala daerah dan DPRD bersifat transaksional. ${ }^{33}$

Sedangkan Partai Golkar menyambut positif usulan penyelenggaraan pemilihan kepala daerah serentak menyusul putusan Mahkamah Konstitusi soal pemilu serentak. Wakil Sekretaris Jenderal Partai Golkar, Nurul Arifin, mengatakan, Pemilukada serentak dapat dilaksanakan bersamaan dengan pemilu presiden (pilpres) dan pemilu legislatif (pileg) pada 2019. Isu itu saat ini masih dalam pembahasan antara pemerintah dan DPR melalui Rancangan UndangUndang (RUU) Pemilukada. Wacana pelaksanaan Pemilukada secara serentak semula diusulkan oleh Kementerian Dalam Negeri (Kemendagri) sebagai pihak

\footnotetext{
${ }^{31}$ http://politik.news.viva.co.id. Hemat biaya pilkada diusulkan serentak. Diakses 2 Pebruari 2014.

${ }^{32}$ Ibid.

33 http://www.republika.co.id/berita/nasional/politik. putusan mk dinilai pengaruhi pilkada serentak. Diakses 2 Pebruari 2014.
} 
pemerintah. Tetapi, pasca putusan Mahkamah Konstitusi (MK) Pemilu serentak pada 2019, di DPR akhirnya mencuat pula wacana Pemilukada serentak. Pertimbangan pelaksanaan Pemilukada serentak adalah terbentuknya koalisi permanen yang terbentuk sebelum pelaksanaan pemilu. Menurut Nurul, koalisi yang terbentuk akan permanen antara di tingkat pusat dan daerah. Sehingga desain tentang calon-calon di Pemilukada itu sudah menjadi desain besar jauh sebelum pemilihan legislatif dan pemilihan Presiden yang dilaksanakan satu paket, ini sebenarnya cocok dengan prinsip Golkar yang kampanye satu kesatuan. ${ }^{34}$

Sementara itu, Pengamat Politik Lembaga Ilmu Pengetahuan Indonesia (LIPI) Siti Zuhro, menyarankan, pemerintah dan DPR bisa membuat suatu keputusan bersama bahwa pemilukada juga serentak di daerah. Pemilukada serentak memberikan jeda atau peluang bagi partai-partai untuk memperbaiki internalnya, strategi, taktik, dan energi terfokus pada satu periode. Dengan demikian, partai pasti setuju karena pemilukada serentak ini akan berjalan kalau tidak ada partai yang terancam khususnya setelah Pemilu serentak nanti. Paket Undang - undang (UU) Politik harus disesuaikan karena MK sudah menetapkan Putusan MK No. 14/PUU-XI/ 2013 sehingga pasal-pasal yang tidak sesuai lagi harus dirubah. ${ }^{35}$

Mengenai masuknya proses Pemilukada dalam sistem Pemilu serentak dinilai masih membutuhkan masa percobaan atau pilot project. Hal itu disampaikan pakar ilmu politik dari Lembaga Ilmu Pengetahuan Indonesia (LIPI), Siti Zuhro yang menyetujui wacana dimasukkannya Pemilukada dalam sistem Pemilu serentak. Namun, masih dibutuhkan masa percobaan dalam menerapkan wacana tersebut. Pelaksanaan Pemilukada serentak dapat dilakukan bertahap, misalnya mulai satu Provinsi. Jika berhasil diterapkan pada satu Provinsi, Provinsi lainnya dapat menyusul. Misalnya di Jawa Timur ada 38 kabupaten dan 1 Gubernur. Jika hal ini berhasil, maka akan kita terapkan di berbagai daerah. Pemilukada serentak yang dimaksudnya hanya mencakup pemilihan eksekutif, yakni Gubernur, Bupati, dan Walikota. Sedangkan proses

\footnotetext{
${ }^{34}$ http://nasional.kompas.com. Golkar Dukung Pilkada Serentak 2019. Diakses 2 Pebruari 2014.

35 http://politik.news.viva.co.id. Hemat biaya...Op. Cit.
} 
pemilihan DPRD, baik tingkat satu maupun tingkat dua telah disertakan dalam Pemilu serentak versi putusan Mahkamah Konstitusi. Sebelum berfokus pada waktu pelaksanaan, Pemerintah dan DPR RI harus terlebih dulu berfokus pada pembentukan payung hukum dalam pelaksanaan Pemilukada serentak. Pada intinya, pemerintah bersama DPR harus membuat payung hukum agar pelaksanaan Pemilukada serentak dalam memilih Gubernur, Bupati dan Walikota mempunyai pijakan hukum jelas. ${ }^{36}$

Pelaksana Pemilukada serentak telah diakomodasi melalui Perppu Nomor 1 Tahun 2014 tentang Pemilihan Gubernur, Bupati, dan Walikota yang kemudian disahkan menjadi UU No. 1 Tahun 2015. KPU mulai menindaklanjuti klausul pilkada serentak yang diatur dalam Perppu No. 1 Tahun 2014 tentang Pilkada. KPU memutuskan untuk mengawali pilkada serentak pada September 2015. September dipilih karena dinilai paling tepat kata ketua KPU Husni Kamil Malik, ada konsekuensi atas penetapan waktu pelaksanaan pilkada serentak pada September 2015. Salah satunya, ada sejumlah kepala daerah yang masa jabatannya habis sebelum September. Solusinya Kementerian dalam Negeri akan menunjuk pelaksana tugas (Plt) kepala daerah hingga pilkada serentak dilangsungkan. Jumlah daerah yang akan mengadakan pilkada serentak pada 2015 setelah Perppu pilkada berjumlah 118 daerah. Perppu mengatur bahwa pilkada 2015 hanya berlaku untuk daerah yang masa jabatan kepala daerahnya habis pada $2015 .{ }^{37}$

Dalam proses pengesahan Undang-Undang Nomor1 Tahun 2015, terdapat beberapa poin yang telah disepakati oleh pemerintah dan panitia kerja DPR, yaitu: Pertama, pelaksanaan Pilkada serentak akan dimulai pada Desember 2015. Kedua, pada Pasal 3 ayat (2) Perpu No. 1 Tahun 2014 yang menyatakan bahwa, Calon Gubernur, Calon Bupati, dan Calon Walikota yang dapat mengikuti Pemilihan harus mengikuti proses Uji Publik. Tahapan uji publik tersebut dihapus. Ketiga, dalam pilkada serentak nanti tidak ada lagi ambang minimal bagi pasangan calon pemimpin daerah untuk memenangkan pesta demokrasi tersebut. Peraih suara terbanyak yang akan memenangkan pilkada. Keempat, ambang batas

${ }^{36}$ Zuhro.@yudistira. http://www.lensaindonesia.com. Siti zuhro jawa timur bisa jadi pilot project pilkada serentak.html. Diakses 2 Pebruari 2014.

${ }^{37}$ Jawa Pos, 22 Oktober 2014. 
bagi calon independen yang ingin berpartisipasi dalam pilkada telah disepakati mengalami kenaikan. Syarat dukungan penduduk untuk Calon Perseorangan dinaikkan yaitu naik 3,5 persen. Kelima, Pembiayaan Pilkada dari APBD didukung APBN. Keenam, lembaga yang menangani sengketa hasil Pilkada adalah Mahkamah Konstitusi (MK). Ketujuh, batas minimal umur bagi calon gubernur adalah 30 tahun, dan calon bupati atau wali kota minimal berusia 25 tahun. Para calon pemimpin daerah juga diminta memiliki ijazah pendidikan minimal SLTA atau sederajat sebelum mencalonkan dirinya. Kedelapan, jadwal Pilkada dilaksanakan dalam beberapa gelombang. Gelombang pertama dilaksanakan Desember 2015 untuk yang Akhir Masa Jabatan (AMJ) 2015 dan semester pertama 2016. Gelombang kedua dilaksanakan Februari 2017 untuk Akhir Masa Jabatan semester kedua 2016 dan seluruh yang Akhir Masa Jabatan 2017. Gelombang ketiga dilaksanakan Juni 2018 untuk yang Akhir Masa Jabatan 2018 dan Akhir Masa Jabatan 2019. Pilkada Serentak secara nasional dilaksanakan 2027. Kesembilan, KPU dan Badan Pengawas Pemilu (Bawaslu) dipercaya oleh Pemerintah dan DPR untuk menjadi penyelenggara pilkada langsung serentak.

Persoalannya adalah, bagaimana jika terjadi sengketa pada pelaksanaan Pemilukada serentak, tidak mungkin satu institusi memeriksa dan memutus beratus-ratus kasus sengketa Pemilukada dalam waktu yang bersamaan. Proses penyelesaian sengketa Pemilukada juga mempunyai batas waktu yang telah ditentukan. ${ }^{38}$ Untuk itu, lembaga yang dianggap paling pas menangani sengketa Pemilukada adalah Mahkamah Agung dengan mendelegasikan kepada Pengadilan Tinggi di tiap-tiap daerah. Jika pihak yang berperkara tidak puas dengan putusan Pengadilan Tinggi maka, dapat mengajukan keberatan ke Mahkamah Agung. Sementara UU No. 1 Tahun 2015 masih menyerahkan kepada Mahkamah Konstitusi untuk menyelesaikan sengketa Pemilukada.

38 Pasal 13 ayat (1) Peraturan MK No. 15 Tahun 2008 tentang Pedoman Beracara Dalam Perselisihan Hasil Pemilihan Umum Kepala Daerah menyatakan bahwa, Putusan mengenai perselisihan hasil Pemilukada diucapkan paling lama 14 (empat belas) hari kerja sejak permohonan dicatat dalam Buku Registrasi Perkara Konstitusi. 


\section{Penutup}

Jadwal Pilkada dilaksanakan dalam beberapa gelombang, gelombang pertama dilaksanakan Desember 2015 untuk yang Akhir Masa Jabatan (AMJ) 2015 dan semester pertama 2016. Gelombang kedua dilaksanakan Februari 2017 untuk Akhir Masa Jabatan semester kedua 2016 dan seluruh yang Akhir Masa Jabatan 2017. Gelombang ketiga dilaksanakan Juni 2018 untuk yang Akhir Masa Jabatan 2018 dan Akhir Masa Jabatan 2019. Pilkada Serentak secara nasional dilaksanakan 2027.

Pilkada serentak ini masih menyisakan persoalan berkaitan dengan sengketa yang akan muncul pada pelaksanaan Pilkada serentak tersebut. Sebab, UU No. 1 Tahun 2015 masih menyerahkan ke Mahkamah Konstitusi (namun sifatnya sementara). Untuk itu, perlu segera dibentuk peraturan perundangundangan yang mengatur mengenai lembaga mana yang berwenang untuk menyelesaikan sengketa Pilkada serentak.

\section{Daftar Pustaka}

Agustina, Leo, Pilkada dan Dinamika Politik Lokal, Cetakan I, Pustaka Pelajar, Yogyakarta, 2009.

Arbas, Cakra, Jalan Terjal Calon Independen Pada Pemilukada Di Provinsi Aceh, Sofmedia, Jakarta, 2012.

Isnaeni Ramdhan, Muchamad, Kompedium Pemilihan Kepala Daerah (Pilkada), Badan Pembinaan Hukum Nasional Departemen hukum dan HAM RI, Jakarta, 2009.

Lutfi, Mustafa, Hukum Sengketa Pemilukada Di Indonesia Gagasan Perluasan Kewenangan Konstitusional Mahkamah Konstitusi, Cetakan Pertama, UII Press, Yogyakarta, 2010.

Mahfud MD, Moh., “Evaluasi Pemilukada Dalam Perspektif Demokrasi dan Hukum" Ceramah Kunci dalam Seminar Nasional Evaluasi Pemilukada: Antara Teori dan Praktik, diselenggarakan oleh Mahkamah Konstitusi pada Rabu-Kamis, 25-26 Januari 2012 di Hotel Sultan Jakarta.

Perdebatan Hukum Tata Negara Pasca Amandemen Konstitusi, Cetaka ke-2 RajaGrafindo Persada, Jakarta, 2011.

Mahmud Marzuki, Peter, Penelitian Hukum, Edisi Pertama,Cetakan Ke-4, Predana Media Group, Jakarta, 2008. 
Manan, Bagir, Menyongsong Fajar Otonomi Daerah, FH UII Yogyakarta, Cet. III, Yogyakarta, 2004.

Morison, Hukum Tata Negara Era Reformasi, Ramdina Prakarsa, Jakarta, 2005.

Saraswati, Retno, "Calon Perseorangan: Pergeseran Paradigma Kekuasaan Dalam Pemilukada" , dalam Masalah-Masalah Hukum, Nomor 2 Jilid 40, April 2011.

Suharizal, Pemilukada, Dinamika, dan Konsep Mendatang, Jakarta, Raja Grafindo Persada, 2011.

Wahidin, Samsul, Hukum Pemerintahan Daerah Mengawasi Pemilihan Umum Kepala Daerah, Cetakan 1, Yogyakarta: Pustaka Pelajar, 2008.

Faizal Rizki http://www.aktual.co/politik. Nu menilai pilkada langsung lebih baik ditiadakan.Diakses tanggal 4 Januari 2013.

http://nasional.kompas.com. Golkar Dukung Pilkada Serentak 2019. Diakses 2 Pebruari 2014.

http://news.detik.com.langkah mundur jika pemilihan kepala daerah kembali ke tangan dprd. Diakses 10 Januari 2013.

http://politik.news.viva.co.id. Hemat biaya pilkada diusulkan serentak. Diakses 2 Pebruari 2014.

http://www.metro7.co.id. Solusi Pilkada Langsung.html. Di akses 3 Januari 2013. http://www.pewarta-kabarindonesia.blogspot.com. Di akses 2 Januari 2013.

http://www.republika.co.id/berita/nasional/politik. putusan mk dinilai pengaruhi pilkada serentak. Diakses 2 Pebruari 2014.

http:/ / www.seputar-indonesia.com. Diakses 7 Januari 2013.

Jawa Pos, 22 Oktober 2014.

Peraturan MK No. 15 Tahun 2008 tentang Pedoman Beracara Dalam Perselisihan Hasil Pemilihan Umum Kepala Daerah.

Putusan Mahkamah Konstitusi No.072-073/PUU-II-2004.

Putusan Mahkamah Konstitusi Nomor 14/PUU-XI/ 2013.

Sekretariat Jenderal MPR RI,"Risalah Rapat Panitia Ad Hoc I (Sidang Tahunan 2000)", Buku kedua jilid 3C, 2000.

Zuhro.@yudistira. http://www.lensaindonesia.com. Siti zuhro jawa timur bisa jadi pilot project pilkada serentak.html. Diakses tanggal 2 Pebruari 2014.

Undang-Undang Nomor 1 Tahun 2015 tentang Pemilihan Gubernur, Bupati, dan Walikota. 